\title{
KITEKINTÖ
}

\section{AZ EURÓPAI UNIÓ BŐVÍTÉSI POLITIKÁJÁNAK ELMÉLETE ÉS GYAKORLATA HORVÁTORSZÁG PÉLDÁJÁN}

\author{
(Theoretical and Practical Approach of the EU's Enlargement \\ Policy: the Croatian Case)
}

LÖRINCZNÉ BENCZE EDIT

Kulcsszavak:

EU bővitési folyamat a bövités alapelvei Horvátország csatlakozása

A tanulmány az Európai Unió bôvitéseinek folyamatjellegére helyezi a hangsúlyt, s ennek ábrázolása során bemutatja az alapelvek, a kritériumok és a menetrend folyamatos változását, nehezedését és a konstans bövitési stratégia hiányát. Ezen elméleti alapvetés egy konkrét példán, a horvát csatlakozás esélyeinek és problémáinak vizsgálatán nyer bizonyitást.

\section{Bevezetés}

A tanulmány az Európai Unió bóvítési politikảját meghatározó függó változók, valamint szubsztantív tényezők vizsgálatára helyezi a hangsúlyt. Ennek során tisztázásra keriul a bővítés fogalma, az ezt meghatározó alapelvek és normák. A cikk végigkíséri ezen szabályozók fokozatos változásait, melynek során megvizsgálja a Szerződések bővítésekre vonatkozó elöírásait, a bỏvítési kritériumokat és alapelveket, valamint az ehhez kapcsolódó dokumentumokat, a csatlakozási folyamatban részt vevök körének és szerepének, s a bővítés menetrendjének változásait, s rámutat arra, hogy mindezek hogyan érvényesülnek a horvát csatlakozási folyamat során.

Tanulmányunkban arra a kérdésre keressük a választ, hogy vannak-e a Közösség bővítési politikájának alapvetései, állandó elemei, s az eddigi tapasztalatok alapján kiszámítható-e a további bỏvítés? Milyen változásokon ment keresztül a bóvítési politika, s ezeknek milyen indítékai voltak? Miért jelent fordulópontot a keleti bỏvítés, s az ekkor kialakult normák hogyan realizálódnak a horvát bóvítési folyamatban, $\mathrm{s}$ vajon érvényesek maradnak-e a további csatlakozások esetében is? 


\section{Az Európai Unió bővítési politikájảnak fogalmi tisztázása}

Az Európai Unió bővítési politikájának vizsgálatakor a kiindulópontot a bővítés fogalmának meghatározása, $\mathrm{s}$ annak a tisztázása jelenti, hogy mit is értünk a Közösség bővítésén. Annak ellenére, hogy magával a bővítéssel foglalkozó szakirodalom igen széles, konkrét definíciót kevés esetben találunk, $\mathrm{s}$ ha igen, akkor is meglehetősen eltérö magyarázatok látnak napvilágot.

A legegyszerübb értelmezés szerint - mely nem csak az EU-ra vonatkoztatható a bövítés általában olyan folyamat, melynek során egy kívülálló valamely nemzetközi vagy regionális szervezet tagja lesz. Glenn szerint a bővítés olyan formális folyamat, mely során egy harmadik fél számára lehetővé válik a taggá váláshoz vezetö tárgyalások megkezdése és lefolytatása (Glenn 2003). Mindkét definíció túlságosan leegyszerüsítve és egyoldalúan kezeli a bỏvítést, ugyanis az integrációval foglalkozó szakértők szerint az uniós bővítés ennél komplexebb folyamat.

Több szerző is azt hangsúlyozza, hogy a bővítés az Unió kifelé irányuló cselekvöképessége (Ginsberg 1989; Grabbe 2000; Hill 2000), míg mások olyan politikaformáló- és átalakító (polity-building és polity-transformation) folyamatként ábrázolják, mely az európai integráció szerves része (Pierson 1995; Schmitter 1996; Monar 2000; Zielonka 2001)!

Grabbe több munkájában azt is kiemeli, hogy egészen a hidegháború végéig a Közösség elsősorban gazdasági integráció volt, de az 1990-es évektől kezdve egyre jelentősebb külpolitikai tényezővé vált. A Közösség kiterjedése és súlya a bővítésekkel tovább nő, gazdagabb kereskedelmi szövetséggé, nagyobb piaccal és erősebb gazdasági hatalommal rendelkező regionális szereplövé formálódik (Grabbe 2003a).

Sedelmeier szerint a bővítés nem más, mint az Unió stabilitásának és megerősítésének módja, melynek során a közösségi normákat, szabályokat és értékeket transzferáljuk, ezek átvételére és alkalmazására ösztönözzük a harmadik országokat. A bövítés tehát egyrészt az EU által alkalmazott olyan eszköz, mely biztosítja a perifériájản a biztonságot és stabilitást, így nem más, mint a külpolitika egyik megnyilvánulási formája. Másrészt nem hagyható figyelmen kívül a bỏvítés szociális, normatív faktora sem, mely az uniós identitás kiszélesítését, valamint az alapvető emberi jogok és demokratikus értékek térbeli kiterjedését is magával hozza (Sedelmeier 2003).

A konstruktivista szemlélet egyik doyenje, Schimmelfennig adja a bỏvítés értelmezésének egyik legárnyaltabb és a változásokat is magában foglaló megfogalmazását. Ezek szerint az Európai Unió bỏvítése olyan lassan, apró lépésekben lezajló folyamat, melynek során a közösségi normák és szabályok fokozatosan és horizontálisan intézményesülnek. A megvalósítás már a tárgyalási szakaszban elkezdődik, $\mathrm{s}$ még a teljes jogú tagság elérése után is tart. A bővítés nem más, mint egy horizontális intézményesülés, vagyis a tagállamok és a csatlakozni akaró országok közötti olyan, egyre kiteljesedö kapcsolat, mely végül elvezethet a bővítéshez (Schimmelfennig-Sedelmeier 2005). 
Schimmelfennig szerint a bővítési folyamathoz négy alapvető esemény kapcsolható. Az intézményesülés az első lépcsőfok, melynek során az Unió és egy harmadik ország között létrejön a kapcsolatfelvétel és párbeszéd. Ezt követi a csatlakozási kérelem benyújtása, majd a bővülési folyamat legfontosabb része, a tényleges csatlakozás. A negyedik lépés az Unió történetében elméleti, hiszen a Közösség dönthet a kizárásról is (Schimmelfennig 2005).

Gazdag Ferenc szerint a bővítés az Európai Unió második pillérének, a Közös kül- és biztonságpolitikának a meghatározó eleme és egyik legfontosabb területe, mely nem vonatkozik minden európai államra. A Közösségen kívüli országok esetében két megnyilvánulási formája létezik, egyrészt a teljes jogú tagság (the prospect of membership) és a 2004 májusában meghirdetésre kerülő Európai Szomszédsági Politika (European Neighbourhood Policy). Elöbbi alá tartozik Horvátország és a többi nyugat-balkáni állam, valamint Törökország (mely esetében újabb fogalom, a stratégiai partnerség is felmerült). Utóbbi - mely nem tartalmazza az uniós tagság ígéretét - a Közösség határain található államokban a fejlödés elősegítését és stabilitás megteremtését támogatja, mélyebb politikai kapcsolatok vagy gazdasági integráció nélkül. Ide sorolhatóak a keleti államok - így Belorusszia, Moldávia, Ukrajna és Oroszország - és a Mediterrán Térség, ahol a Barcelonai folyamat, majd annak újjáélesztése, az „Unió a Mediterráneumért” keretében az EU segíti a kapcsolattartást a Földközi-tenger medencéjében található EU-tagállamok és a partner-országok között (Gazdag 2005).

Mindez azt is tükrözi, hogy az Unió a további bővítések során új és véglegesnek tekinthető tárulási formák megvalósításán färadozik, mely egyrészt jobban megfelel a kevésbé fejlett államok részleges integrálásának, de nem jelentenek teljes tagságot, másrészt a Közösséget sem terhelik meg sem gazdaságilag, sem szociálisan, sem politikailag.

Munkánkban a fenti szempontok figyelembevételével foglalkozunk a Közösség térbeli kiterjesztésének problematikájával. Ennek alapján az általunk használt értelmezés szerint a bővítés meghatározó elemei a folyamatosság, a fokozatosság és a horizontális intézményesülés. A Közösség bövítése a regionális integráció olyan lényeges eleme, mely nem csak az Európai Unió külső cselekvőképességét növeli meg, hanem alapvető belső intézményi, gazdasági, kulturális változásokat eredményez, s növeli a közös politikák kiterjesztésének és elmélyítésének lehetőségeit.

\section{Az Európai Unió bővitései}

A Közösség történetét végigkísérik a bővítések, melyek mindig is erősítették a kontinens biztonságát, elősegítették azt, hogy a Közösség súlya a nemzetközi politikában és a globális gazdasági rendszerben egyre jelentősebbé váljon. A bővítések nem csak külpolitikailag erösítették a Közösséget, hanem belsőleg is, hiszen általában együtt jártak az integráció mélyülésével is, elősegítették a kohéziót, a szervezet konvergenciáját (Inotai 1997b; Avery-Cameron 2001). 
A bővítés bár folyamatos volt, mégis kronologikusan két jól elkülöníthető szakaszra osztható. Az első etap 1973-ban kezdődött és az 1995-ös bővítésig tartott. Ebben a periódusban csak olyan országok csatlakoztak a Közösséghez, amelyek a vasfüggönytöl nyugatra helyezkedtek el, s amelyek politikai és gazdasági berendezkedése többé-kevésbé hasonló volt, hiszen müködésük demokratikus alapelveken nyugodott, s tỏkés piacgazdasággal rendelkeztek. Ebben a szakaszban négy alkalommal került sor az integráció kiterjesztésére. A folyamat számtalan kérdést, vitát generált, de ténylegesen soha nem kérdőjeleződött meg a szükségessége. Annyira, hogy az EK még olyan országokkal is aláirta a Társulási Szerzödéseket, mint Törökország (1963), Málta (1970) és Ciprus (1972), amelyek messze álltak az európai normáktól (Wallace 2002).

A második periódus a rendszerváltással indul, s valójában nagy dilemmát jelent ma is a Közösség számára. Ezt tükrözi az is, hogy hosszú ideig nem tudott mit kezdeni és egységes álláspontot kialakítani az ajtaján kopogtató volt szocialista országokkal, hiszen 1993-ig tartott, amíg elhatározta a keleti bővítést és további öt évig, amikor ténylegesen elkezdődhettek a csatlakozási tárgyalások. A probléma gyökerét az jelentette, hogy ezen államok instabil politikai berendezkedése, a demokratikus átalakulás és tökés piacgazdaság létrejöttének befejezetlensége miatt az Unió félelemmel tekintett ezen országokra. Alátámasztotta ezt, hogy a jelöltek éppen az Unióhoz való csatlakozástól remélték a rendszerváltás mielőbbi véghezvitelét és a gazdasági szerkezetátalakítást. Balázs Péter szerint „az Európai Unió keleti irányú bövitése nem az eddigi integrációs terjeszkedés egyszerü folytatása, hanem új integrációs nyitánynak tekinthetón' (Balázs 2001).

A Bizottság akkori elnöke, Jacques Santer is a bővítés mellett tette le voksát 1997-es nyilatkozatában. Szerinte a bővítés „,örténelmi fordulópontot jelent Európa számára, olyan lehetöséget, amely növeli biztonságát, gazdasági potenciálját, kulturális sokszinüségét és a világban betöltött szerepét" (Santer 1997). Nem az volt tehát a kérdés, hogy a vasfüggöny mögötti rendszerváltó országokban támogassák-e az átalakulási folyamatot, visszafordithatatlanná téve azt, illetve, hogy segítsenek-e ezen államoknak beintegrálódni az egységes európai térbe, hanem három stratégiai csomópontra, a mikor, a kivel és milyen feltételekkel kérdésekre keresték a választ ${ }^{2}$.

Az Európai Unió bővítési tapasztalatai meglehetösen széles körüek, hiszen ez idáig túl van 23 sikeres csatlakozási tárgyaláson ${ }^{3}, \mathrm{~s} 21$ ország csatlakozott már a Közösséghez, mely 5 hullámban valósult meg. Az elsö 1973-ban Nagy-Britannia, Írország és Dánia integrálását hozta. 1981-ben került sor Görögország, majd 1986-ban Spanyolország és Portugália belépésére, mely három államot gyakran együtt is emlegetve a „déli vagy mediterrán” bővítésnek hív a szakirodalom. Sajátos része ennek a folyamatnak a Közösség első tényleges keleti irányba történő kiterjedése 1990-ben a német egyesítés kapcsán, melyre úgy tekinthetünk, mint egy tényleges csatlakozás nélküli bőviullésre, ezért a szakirodalom nem is számítja annak, hiszen öt csatlakozási hullámról beszél. A következö állomást az EFTA országok jelentették, amelyek a készülő egységes piac előnyeiből kimaradva sorban jelezték belépési szándékukat. Először Ausztria 1989-ben, majd az Európai Gazdasági Térség keretegyezményé- 
nek tárgyalási tapasztalatai alapján Svédország és Finnország is tagsági kérelmet nyújtott be, s 1995-től az EU tagjává vált.

Ezen csatlakozások kapcsán minden esetben kiújult a vita a bővítés és mélyités relációjában. Minden bővítéskor felerősödött az a félelem, hogy a Közösség gyengébb lesz, a kohézió kisebb, és veszélybe kerülhetnek az eredeti célok és identitás, de soha nem olyan erővel, mint a keleti bővítés kapcsán. Minden tagfelvétel után napirendre kerültek bizonyos intézményi reformok és a közös politikákban történő változtatások szükségessége, de a 2004-es csatlakozáskor ezek is hatványozottan jelentkeztek. Az utolsó, ötödik bővítés sajátossága, hogy differenciált, és valójában két fázisban történt. Először 2004-ben 8 kelet-európai ország, valamint Ciprus és Málta, majd 2007. január elsejétől Románia és Bulgária váltak a Közösség tagjaivá (Avery-Cameron 2001; Wallace 2002).

A bővítések első, 1995-ig tartó szakasza és a keleti bővítés között természetesen vannak hasonlóságok is. A Közösség magjánál fejletlenebb országok csatlakozásának fö szempontja véleményünk szerint mindig is ugyanaz volt. A tagjelöltek modernizációjuk és biztonságuk zálogát látták az Unióban, s ez legalább annyira érdekében állt a tagállamoknak is, hiszen számukra a kontinens biztonsága elsőszámú prioritás, mely nem garantálható a közép- és kelet-európai térség modernizációja nélkül. A bővítések hátterében a biztonságpolitikai célok mellett, kiemelkedő szerepet játszanak a gazdasági elönyök, a nagyobb piac kínálta lehetőségek, melyek lehetóvé teszik a fenntartható fejlődést $\mathrm{s}$ az Unió pozícióinak megörzését a növekvő világpiaci versenyben. Nem elhanyagolhatóak a politikai indítékok sem, de amíg ezeket korábban elsősorban nemzetközi érdekek határozták meg, mára a tagállamok belső, kúlönösen biztonsági, biztonságpolitikai megfontolásai húzódnak meg a háttérben. Minden eddigi bővítés esetében igaz, hogy a gazdasági és politikai érdekek összefonódnak, mert minél stabilabb gazdasággal rendelkezik a tagjelölt állam, annál erősebb a politikai akarat a bövítésre, hiszen a csatlakozás több előnnyel és alacsonyabb költséggel jár. A hasonlóságok között tarthatjuk számon azt is, hogy a később csatlakozó országok - kivéve az EFTA-tagállamokat - a Közösségnél alacsonyabb gazdasági fejlettséggel rendelkeznek, ezért felzárkóztatásuk, a gazdaság fejlesztése összefonódik a piaci integrációs folyamattal.

Abban azonban már eltérés mutatkozik, hogy ennek az uniós fejlesztésnek a mértéke jóval kisebb volt a keleti bővítésnél, $\mathrm{s}$ ráadásul a régió felzárkózásának meg kellett valósulnia még a csatlakozás előtt. A 2004-es bővítés soha korábban nem tapasztalt kihívás elé állította az Uniót, s olyan paradoxonokat eredményezett, amelyek indirekt módon kihatnak a további bỏvítésekre is. A keleti bővités során beigazolódott, hogy minél később csatlakozik egy állam az Unióhoz, annál fejletlenebb az adott ország, így hosszabb ideig tart, és komplikáltabb lesz a felzárkózási folyamata.

Mindebböl levonható az a következtetés, hogy az Unió fejlődésével az egyre komplexebbé váló intézmény- és jogrendszer, valamint a közpolitika bövülése és elmélyülése miatt a csatlakozás is egyre nehezebb lesz, és egyre hosszabb ideig tart, $s$ ez új problémák kialakulásához vezet ${ }^{4}$. Végül paradox helyzetet teremt az a körülmény is, hogy minél fejlettebb az EU, a nettó befizetők annál kevésbé hajlandóak 
az új tagok támogatására. Ezek a negatív tényezök összeadódnak, gerjesztik egymást - $\mathrm{s}$ máris jól láthatóak a horvát csatlakozás nehézségeiben ${ }^{5}$-, ezért legkésőbb az EU28 után a Közösségnek ủjra kell gondolnia bövítési stratégiáját (Ágh 2006a).

Az ezredforduló nem csak Európán belül hozott olyan látványos változásokat, melyek alapvetően átalakították a bővítési folyamatokat, hanem a nemzetközi környezetben is. A globalizáció és az egyre erősődő gazdasági verseny újabb kihívások elé állítja az Európai Uniót, mely kettős szorításban - kínai és amerikai - van, és ha nem akar lemaradni a világméretü versenyfutásban, akkor válaszolnia kell ezekre. A Közösség 1995-ig tartó bővítési folyamata valójában az integráció belső megerösödését segítette, „belügy” volt, de a keleti és további bövítések távolabbi dimenziókat feltételeznek, hiszen globális hatással bírnak. A kérdés az - és a további bövítések esetében is feltehetỏen az lesz, különösen, ha Törökországra gondolunk -, hogy a megnövekedett Európai Unió képes lesz-e ezzel a lépésével javítani világméretü versenyképességét (Inotai 1997a).

A hasonlóságok mellett azonban szembetünő különbségek is vannak. A bövítés változásainak számbavételekor nem elhanyagolhatóak a volt szocialista országok különböző gazdasági, társadalmi és politikai viszonyai, valamint a jelentkezők nagy száma, mely a korábbiaktól eltérö, újfajta eljárás kialakítását tette szükségessé. Mindez legszemléletesebben a csatlakozás kritériumának, feltétel-, jog- és intézményrendszerének átalakulásában, a bővítés szereplőinek, menetrendjének, módszereinek és idősíkjának változásaiban realizálódik. Az alábbiakban ezen dimenziók szempontjából kívánjuk bemutatni a hosszú hagyományokon, valamint stabil jogiés intézményi alapokon nyugvó bővítésben bekövetkezö változásokat, melyek elöször a 2004-es bóvítés során valósultak meg, s a dolgozatban vizsgált Horvátország és a Nyugat-Balkán többi állama esetében is útmutatóak.

\section{Bövités a Szerzödések tükrében}

$\mathrm{Az}$ alapításkor hat taggal bíró Közösség mára 27 tagúvá nőtt, $\mathrm{s}$ a folyamatnak még nincsen vége. Felmerül a kérdés, hogy milyen szempontok, kritériumok alapján csatlakoztak az újabb és újabb országok, s vajon milyen joganyag állt az eddigi bövitések hátterében. Általánosságban elmondható, hogy vannak bizonyos visszatérő, minden bővítést megalapozó normák, ugyanakkor jól látható a szabályozók folyamatos változása, új és új kritériumok megjelenése, a feltételrendszer nehezedése is. Ez azt jelenti, hogy az alapvetések, a fö stratégia kialakítása már az első csatlakozás kapcsán megtörtént, ugyanakkor a normarendszer folyamatosan pontosításra került, s ezen kiegészítések mentén, a megváltozott körülményekhez alkalmazkodva valósult meg a 21 ország csatlakozása.

A bövítés jogi szabályozása mindezek alapján rendkívül komplex és állandóan változó tényezőként határozza meg az újabb tagállamok felvételét. Mindezt alátámasztják a Szerződések bővítésekre vonatkozó elöírásai, a bővítési kritériumok és 
szabályok - közülük legnagyobb hangsúllyal a koppenhágai kritériumok és az ehhez kapcsolódó dokumentumok szerepelnek -, valamint a csatlakozási folyamatban résztvevők körének és szerepének, $\mathrm{s}$ a bővítés menetrendjének változásai. Ezen utóbbi faktorok igen hiányosan és általánosságban szerepelnek az írott jogban, tág teret engedve az értelmezésnek. Az alábbiakban a fenti szabályzók bemutatásával kívánjuk igazolni, hogy melyek azok a visszatérő, minden bővítésnél alkalmazott, tradicionális elemek, amelyek befolyásolják a horvát csatlakozást és melyek azok a később, különösen a 2004-ben csatlakozó országoknál megfogalmazott normák, amelyek szintén kihatással lesznek Horvátországra.

A bővítések jogi hátterének megteremtése öt lépcsőfokban valósult meg, $\mathrm{s}$ azt alapvetően a Szerződésekben megfogalmazott passzusok adják. Már az Európai Szén- és Acélközösséget (ESZAK) létrehozó Párizsi Szerződés 98. cikkelye kimondta, hogy bármely európai állam csatlakozhat a szervezethez, s a végrehajtást teljes egészében a Tanácsra bízta. ${ }^{6}$ A második lépcsőfokot a Római Szerződés jelentette, melyben érvényben maradt az ESZAK 98. cikkelye, de kibővült az Európai Gazdasági Közösség 237. és az Euratom 205. paragrafusával. A három szabályozót azért tartották szükségesnek, mert a tagjelölteknek mindhárom szervezethez egyszerre, de külön-külön kellett csatlakozniuk. Az EGK 237. cikkelye úgy rendelkezett: „Bármely európai állam kérheti felvételét a Közösségbe. Kérelmét a Tanácshoz kell benyújtania, amely a Bizottság véleményének kikérését követően arról egyhangúlag határoz. A felvétel feltételeit és e szerzödésnek a felvétel miatt szükségessé váló kiigazitásait a tagállamok és a felvételét kérö állam közötti megállapodás rendezi. Ezt a megállapodást alkotmányos követelményeinek megfelelóen valamennyi szerződő államnak meg kell erösítenie." (Római Szerzödés 1957 - idézi Fazekas 2001) Jól látható, hogy a Római Szerződés a kormányköziség irányába mozdult el, hiszen a tagállamok jelentős felhatalmazást kaptak a csatlakozási folyamatban. Ez a kitétel változatlan maradt az Egyesítési Szerződésben is.

Ugyanakkor a három érvényben lévő szabályozás egymásnak ellentmondó eszközeivel (nemzetek feletti és kormányközi) megnehezítette a mindennapi alkalmazást, $\mathrm{s}$ ezt az ürt hivatott kitölteni a bővítések kapcsán fokozatosan alakuló szokásjog, melynek szerepe minden, az első bővítést követỏ alkalommal látható.

A harmadik változtatás az Egységes Európai Okmányban fogalmazódott meg, mely az EGK-Szerződés 237. cikkének első bekezdése helyébe a következő rendelkezést léptette életbe: „Bármely európai állam kérheti felvételét a Közösségbe. Kérelmét a Tanácshoz kell benyújtania, amely a Bizottsággal folytatott konzultációt és az Európai Parlament tagjainak abszolut többségével elfogadott hozzájárulását követóen arról egyhangúlag határoz." (Egységes Európai Okmány 1986) Új elemként jelentkezik tehát a Parlament részvétele a bővítési folyamatban.

A negyedik kiigazítás Maastrichttal lépett életbe, ugyanis a Szerződés az Európai Unióról (TEU) O cikkelye megszüntetett minden korábbi szabályozást, de ủjat tartalmában nem hozott, hiszen valójában megismételte az EGK 237. cikkelyének alapvetéseit. 
Az ötödik lépcsőfok az Amszterdami Szerzödés, mely a TEU 49. cikkelyét (átszámozva az $\mathrm{O}$ cikket) módosította, utalva a TEU 6(1) cikkelyre, $\mathrm{s}$ az új tagfelvételi szabályok szerint: „Bármely olyan európai állam kérheti felvételét az Unióba, amely tiszteletben tartja az $F(1)$ cikk bekezdésében megállapitott alapelveket. Kérelmét a Tanácshoz kell benyúitania, amely a Bizottsággal folytatott konzultációt és az Európai Parlament tagjainak abszolút többségével elfogadott hozzájárulását követöen arról egyhangúlag határoz. ” Az $\mathrm{F}(1)$ cikk szerint „Az Unió a szabadság, a demokrácia, az emberi jogok és az alapvetó szabadságok tiszteletben tartása és a jogállamiság elvein alapul, amely alapelvek közösek a tagállamokban" (Amszterdami Szerzödés 1997 idézi Avery-Cameron 2001; Fazekas 2001; Hoffmeister 2002).

Ezen módosításra azért volt szükség, mert a Római Szerződésben foglaltak nem jelentettek megfelelő iránymutatást a bővítésekre, melyeknek a kilencvenes évek közepére új kihívásokkal kellett szembenéznie, hiszen a rendszerváltó országok sem gazdasági, sem politikai berendezkedésüket illetôen nem illeszkedtek az eddigi tagállamokhoz. Ráadásul soha nem került meghatározásra az sem, hogy hol vannak a bővítés földrajzi határai. Erre nem is igazán volt a 2004-es bövítés elött szükség, mert addig csak olyan országok csatlakoztak, amelyek a vasfüggöny nyugati oldalán helyezkedtek el. Ez természetesen nem azt jelentette, hogy mindegyik, a Közösségbe belépő állam a centrum része volt, ellenkezőleg, néhány tagjelölt a periférián helyezkedett el. Ennek ellenére közös vonásuk, hogy részesültek a Nyugat gazdasági összefonódását megalapozó Marshall-segélyböl, müködő piacgazdasággal bírtak, többségük pedig a NATO tagja is volt, így a gazdasági, politikai és biztonsági érdekazonosság megkönnyítette csatlakozásukat, mely egyben megerösítette a Nyugatot a két világrendszer versenyében.

Az Amszterdami Szerződésben megfogalmazott kritériumok azt a csalóka látszatot keltik, hogy az Unió új alapokra helyezte a bővítést. Valójában azonban nem történt megújulás, csupán az eddig jól bevált és alkalmazott gyakorlatot, a szokásjogot ültették be az írott jogi szabályozás kereteibe.

\section{A bövítés kritériumainak és alapelveinek változásai}

A kodifikált jog Szerzödésekben körvonalazott változásai nem adnak választ arra, hogy miért is egyre nehezebb a csatlakozási folyamat. Erre csak a bővítés kritériumainak, alapelveinek, szereplöinek, kronológiájának és eszközeinek elemzése adja meg a választ.

A bővítés kritériumait egy kivétellel tartalmazza a kodifikált jog, $\mathrm{s}$ ezek az államiság, az európaiság, az Amszterdami Szerződésben megfogalmazott demokratikus jogok. Az írott jogból hiányzó elem, hogy a jelölt legyen tagja az Európa Tanácsnak, márpedig az eddigi bővítések azt mutatják, hogy ez minden esetben megelözte a csatlakozást. Ha ezeket a kritériumokat Horvátországra vetítjük, jól látható, hogy 
ezek szerint nincsen akadálya csatlakozásának, hiszen 1992 óta önálló európai állam, ahol érvényesül a jogállamiság, és 1996-tól tagja az Európa Tanácsnak is.

A bỏvítés három alapelvének megfogalmazására az elsỏ csatlakozási folyamatban sor került, s ezek azóta látszólag változatlanul meghatározzák az újabb tagok felvételét.

1) A bővítés első sarokköve a Hágai Európai Tanács 1969. december 1-2. kommünikéjében került kialakításra, mely szerint a tagjelölttel a tárgyalások csak akkor kezdődhetnek meg, ha az elfogadta a Szerződéseket és azok politikai céljait.

2) A második, talán a legnehezebben teljesíthető bővítési elv az acquis communautaire teljes elfogadása, hiszen az integrációs szabályrendszer jelentősen megnövekedett a 2004-es bővítést megelőző időszakban. Ez természetesen következik abból, hogy mivel a Közösség történetét bővítések sorozatának fogjuk fel, melynek során a szervezet minél nagyobbra nő, annál több integrációs funkciót valósít meg, s ez egyre bonyolultabbá teszi a belépési folyamatot. A keleti csatlakozást megelözően kb. 80000 oldalnyi joganyag mára 100000 oldalnyira növekedett, hiszen már magában foglalja a Maastrichtban létrehozott második és harmadik pillért, valamint a politikai, gazdasági és monetáris unió célkitűzéseinek elfogadását és teljesítését, Schengent, a Monetáris Uniót, az Amszterdami és Nizzai Szerződéseket, az Unió által létrehozott új politikákat, rendeleteket és határozatokat. A jelölteknek át kell venniük az EU nem kodifikált joganyagát, ső́t a nem kötelezỏ jellegü ajánlásokat és véleményeket is.

Tovább fokozza a csatlakozás előtt állók nehézségeit, miszerint nem elégséges, ha az acquis a nemzeti jog részévé válik, mert a tagjelöltnek az Európai Tanács 1997. évi luxemburgi határozata $(25 . \S)$ értelmében azt is bizonyítaniuk kell, hogy alkalmazásának intézményi kapacitását is megteremtették (Council... 1997). Mindez a közösségi vívmányoknak az Unió részéről történő maximalista értelmezését tükrözi. Ráadásul az Amszterdami Szerződés fontos elemeként jelentkezik a korlátozott rugalmasság (flexibility) elvének kimondása, mely szerint a tagjelöltek az acquis elfogadásakor nem hivatkozhatnak a tagállamok korábbi mentességeire, nem áll fenn számukra az opt-out (kimaradás) lehetősége, melynek legbeszédesebb példája éppen Schengen és az EMU. Ilyen módon az a paradox helyzet áll elö, hogy a leendő tagok maradéktalanabbul teljesítik és teszik magukévá a közösségi vívmányokat, mint a már kapun belül lévök (Council... 1997; Grabbe 2001; 2003a).

3) A harmadik alapelv kimondja, hogy a taggá válás utáni átmeneti időszakot szigorúan be kell határolni, nem tarthat túlságosan hosszú ideig, s nem lehet a Szerzödésekben foglaitaktól és a Közösség szabályaitól jelentősen eltérô derogációkat megfogalmazni.

4) A legutolsó, keleti bővítéskor is ezen három tradicionális alapelv érvényesült, ugyanakkor ezek teljesítése nem győzte meg a tagállamokat a jelöltek alkalmasságáról, ezért a Közösség megteremtett egy negyedik alapelvet, a kondicionalitás (feltételesség) elvét, mely szintén alátámasztja azt a hipotézist, hogy az Európai Unió bővítéseiben új szakasz nyílott 2004-ben. A Közösség ugyanis garanciákat szeretett volna kapni arra vonatkozóan, hogy a demokratikus átalakulás és piacgazdaság ki- 
alakulása még a csatlakozás előtt megvalósul a közép- és kelet-európai államokban, s ezzel nem veszélyezteti az Unió eddig elért eredményeit. A tagállamok az 1993. évi júniusi koppenhágai csúcson az ún. koppenhágai kritériumokkal megteremtették a kondicionalitás jogi alapját (Hillion 2002):

- Stabilan müködő demokratikus intézményrendszer, mely garantálja a jogállamiság és az emberi jogok érvényesülését, és biztosítja a kisebbségek védelmét, jogaik tiszteletben tartását (politikai kritériumok);

- Múködő piacgazdaság és annak a képességnek a megszerzése, hogy az ország meg tudjon birkózni az Unióban meglévő piaci erök versenyével (gazdasági kritériumok);

- Képesség a tagsággal járó kötelezettségek, a teljes közösségi joganyag átvételére és alkalmazására, különösen a politikai, gazdasági és pénzügyi unió célkitủzéseinek vállalására (jogi, intézményi kritériumok).

- Mindehhez egy negyedik, a Közösség számára megfogalmazott kitétel is társult, mely szerint az Uniónak alkalmasnak kell lennie új tagok befogadására (European Council 1993).

A kondicionalitás, mint alapelv megjelenése több szakértő szerint kifogásolható, ugyanis érvényesítése azt jelentette, hogy a 2004-ben csatlakozott tíz állam - és a sorban következő Horvátország - jóval felkészültebb, mint a 15 EU-tag.

Mindhárom koppenhágai kritérium jól láthatóan általánosságban kerül megfogalmazásra, nem sorolja fel pontosan a célokat, nem tartalmaz világos számszerüsíthetó adatokat, arról pedig végképp nem tesz említést, hogyan lehet ezeket teljesíteni, s éppen ezért tág teret enged az értelmezésnek. Soha nem került explicit módon definiálásra, mit ért az Unió a demokrácia, a piacgazdaság fogalmán, vagy mit jelent, hogy a jelölteknek képeseknek kell lenniük arra, hogy megbirkózzanak az Unióban uralkodó versenyhelyzettel.

Még nagyobb a bizonytalanság az állandóan változó és növekvő acquis esetében, mely a 2004-es bővítés elött igen tág keretek között került meghatározásra, s mindössze annyit mondtak, hogy magában foglalja az EU-nak és intézményeinek működéséből fakadó valóságos és lehetséges jogait és kötelezettségeit. Ez a definíció lehetőséget ad minimalista és maximalista értelmezésre egyaránt, de jól látható, hogy a Közösség egyre inkább a maximalista irányzat felé tendál. Ez a bizonytalanság olyan fegyvert ad az Unió, s elsösorban az Európai Bizottság kezébe, hogy az a tagjelöltekről készült éves jelentéseiben szabadon definiálhatja, hogy mely ország mikor és hogyan teljesítette a feltételeket. Ráadásul mindhárom feltételt végre kell hajtani a sikeres csatlakozáshoz, így például Horvátország esetében nem elégséges, hogy jól teljesít a gazdasági szférában, ha egyéb területeken (menekültek, háborús bünösök, igazságszolgáltatás reformja) elmarad az uniós kívánalmaktól, mert ez a csatlakozás elodázhatóságát vonhatja maga után (Grabbe 2003b).

A fentiek függvényében jól látható, hogy a keleti és a további bővítések során a tagjelöltek számára a csatlakozás politikai és gazdasági feltételei jelentősen meghaladták a korábbiakat, s a Közösség soha ezt megelőzően nem támasztott ilyen magas köve- 
telményszintet. Ugyanez a kitétel igaz a horvát esetre is. Ellentmondásossá teszi a kérdést az is, hogy ezen országok, bár alacsonyabb fejlettségi szintről indultak, sokkal kevésbé számíthattak az uniós fejlesztési politikára és forrásokra, s így kellett a szigorúbb kritériumoknak megfelelni. Ez a magas feltételrendszer lehetövé tette a Közösség számára, hogy a kritériumok bármikor alkalmazhatóak legyenek a keleti bövítés magakadályozására, lassítására, esetleg elhalasztására. Utóbbi legnyilvánvalóbb jelei a román és bolgár csatlakozás elodázásakor mutatkoztak meg. Ezek a kritériumok a csatlakozás elött álló Horvátország esetében is fennállnak, sőt halasztó hatályával is találkozhattunk, amikor 2005. március 16-án - egy nappal a tárgyalások megkezdése elött - az Unió a tárgyalások elhalasztása mellett döntött azzal az indokkal, hogy Zágráb nem müködött kellőképpen együitt a Hágai Nemzetközi Törvényszékkel.

A 2004-es bővítéskor új elemként jelentkezett, hogy az Unió akkor szigorította a feltételeket, amikor egyébként is nehéz megfelelni az elvárásoknak a megnövekedett joganyag következtében. A korábbi bővítések esetében is át kellett venni a belső joganyagot, de ez lényegesen kevesebb volt, ugyanakkor általában hosszú átmeneti időszak állt rendelkezésre, amelynek megvalósításához jelentős pénzügyi transzfer is biztosított volt. A szigorodó feltételrendszer alkalmazására magyarázatot ad, hogy egyrészt maga az Unió is változik, másrészt tart a volt szocialista országok kevésbé fejlett viszonyaitól. A keleti - és a leendő horvát - bővítés esetében nemcsak az egyre bővülő joganyag átvétele jelentette/jelenti a gondot, hanem az is, hogy a rendszerváltás költségeit ezen államok saját maguk állták, melyhez még hozzájárult a belső piac igényeihez való igazodás is. A korábban csatlakozott, kevésbé fejlett országok mindennek a megvalósítására jelentős pénzügyi támogatást is kaptak. Most az a helyzet állt elö, hogy a térség országainak a Közösségen kívül kell „EU-éretté” válnia.

Nehezítő körülmény, hogy a rendszerváltó országokkal megkötött Társulási Szerződések, valamint a Nyugat-Balkán államaival aláírásra kerülő Stabilizációs és Társulási Megállapodások megteremtették a szabadkereskedelmet, amely a tagállamok számára lehetővé tette a térség gazdasági előnyeinek egyoldalú kihasználását. Az így kialakult aszimmetrikus interdependencia - mely soha nem volt jellemző a korábbi bővitéseknél - negativan hatott a tagjelöltek gazdasági viszonyaira (Friis-Murphy 1999; Balázs 2001; Moravcsik-Vachudova 2003; Horváth 2005).

A Nyugat-Balkán államai esetében az Európai Unió speciális programot, a Stabilizációs és Társulási Folyamatot (Stabilisation and Association Process; SAP) alakított ki, melyet az Európai Bizottság 1999. május 26-án hirdetett meg. A SAP a közösség politikai programja a térség biztonságának és fejlödésének megvalósítására, az Európai Unió legföbb eszköze a Thesszaloniki Agendában foglaltak végig vitelére, egy hosszú távú keretprogram, mely magában foglalja a katonai és politikai biztonságot, a piacgazdaság megvalósítását, a regionális kapcsolatok és együttmüködések támogatását és megteremti a térséghez tartozó országok és az EU kapcsolatainak stratégiai kereteit. A SAP távolabbi célja a tagjelöltség külső és belső feltételeinek megteremtése (European Commission 1999). 
A SAP kritériumainak teljesítése előfeltétele a folyamat legfontosabb elemének, a Stabilizációs és Társulási Megállapodásnak (SAA), melynek rendkívül fontos szerepe abban rejlik, hogy aláirásával speciális szerződéses viszony alakul ki a jelölt, az Unió és annak tagállamai között. A megállapodások sajátossága, hogy nem bilaterális jellegủek, mert a Közösség és külön-külön minden tagállam, valamint az adott nyugat-balkáni ország között köttetik. A Stabilizációs és Társulási Megállapodások a tíz közép- és kelet-európai tagjelölt országgal kötött Európai megállapodásokhoz hasonlithatóak, ugyanakkor lényegesen több és szigorúbb feltételt szabnak az új államoknak, ráadásul csak a Tanács jóváhagyásával, a Parlament hozzájárulásával és minden tagállam ratifikációjával léphetnek életbe. Ez is magyarázatot ad arra, hogy miért tartott nyolc évig, míg az utolsó nyugat-balkáni állammal is aláirták a megállapodást, s Horvátország és Macedónia kivételével miért vannak még mindig folyamatban a ratifikációk.

Horvátországgal az SAA aláirásra 2001, október 29-én került sor, s a megállapodást a horvát parlament 2001. december 5-én, az Európai Parlament pedig december 12-én ratifikálta. Ezzel Horvátország és az Európai Unió között először jött létre szerződéses viszony, melynek életbe lépésére azonban még hosszú ideig - 2005. február 1-ig - várni kellett, hiszen minden tagállam ratifikációjára szükség volt, s az Unió éppen történetének addigi legnagyobb mértékủ bővítésével volt elfoglalva. Az egyezményhez csatolt klauzulában megfogalmazták, hogy az ország elnyerte az EU-tagság potenciális jelöltjének státuszát (European Commission 2001).

Az SAA-t összehasonlítva az európai megállapodásokkal, látható, hogy jelen esetben a hangsúly nem a csatlakozáson, hanem a stabilizáción van. Az elnevezés megváltoztatása is ezt tükrözi, melyben mindemellett szerepet játszott az is, hogy a tagállamok nem értettek egyet a bỏvítés kérdésében, ezért a látszatát is el kívánták kerülni annak, hogy a Megállapodás megkötése után nyitva áll az út az EU-ba (mely a közép- és kelet-európai országok számára adott volt). Ezért az aláíró nyugat-balkáni államok továbbra is potenciális jelöltek maradnak, s a megállapodás utalást sem tett arra, hogyan érhető el az uniós tagság (Phinnemore 2003).

A koppenhágai kritériumok nem csak a keleti csatlakozást nehezítették, hanem egyértelmủen gyengítették a tagjelölt állam alkupozicióját, merevebbé tették a bővítés szabályozását, $\mathrm{s}$ ez a folyamat a jelenlegi aspiránsok helyzetét is körvonalazza. A kritériumok megfogalmazásával és az ahhoz való feltétlen ragaszkodással az Uniónak kevés manőverezési lehetősége van a tárgyalások során, hiszen azt alapvetően a kondicionalitás, az uniós kívánalmak teljesítése határozza meg. A tárgyalás sorản az alkupozíciókat az EU javára billenő strukturális aszimmetria jellemzi. Ez az egyenlőtlenség nem csak a Közösség jóval erősebb érdekérvényesítő erejéből fakad, hanem legalább annyira a tagjelölt gyengeségén is múlik (Grabbe 1999; Maršić 2006).

A kritériumok megfogalmazása lehetőséget biztosít a Közösség számára, hogy a jelöltek közül kiválasztva a legsikeresebben teljesítöket, csak azokkal kezdje meg a tárgyalásokat. Így a bỏvítés új elemeként jelenik meg - soha korábban nem alkalmazták - a differenciálás elve, melyet az Unió arra használ fel, hogy ezzel motiválja a feltételek minél gyorsabb teljesítését. Ennek érdekében a keleti bővítés kapcsán 
1997-től kezdve egészen a 2003. november 5-én megjelenő monitoringig, a NyugatBalkán esetében 2002 és 2004 között a térségre vonatkozó éves jelentésekben, 2005-töl a Bizottság ország-jelentéseiben értékeli a tagjelöltek gazdasági, társadalmi és politikai elörehaladását, évröl-évre elmélyítve és szélesebb körben vizsgálva az elömenetelt és megfogalmazva a csatlakozásra várók számára a legfontosabb feladatokat.

A keleti bỏvítés kapcsán megszülető jelentések éveken keresztül kimutatták, hogy melyek a kevésbé és melyek a jól teljesítő államok, $\mathrm{s}$ utóbbiak ezért abban bíztak, hogy első körben csatlakozhatnak. A csatlakozási tárgyalások kezdetén a differenciálás elve volt a meghatározó, s ez éles versenyre sarkallta a tagjelölteket. A keleti bővítésnél is először csak a legfejlettebb hat tagjelölttel indultak meg a csatlakozási tárgyalások. 2001-ben azonban az Unió váratlanul sutba dobta a differenciálást és a "méltányosság” elvének alkalmazásával a „mindenki egyszerre csatlakozik” formula, a „Big Bang” mellett döntött.

A „Big Bang” típusú bóvítés több szempontból is kedvező lépés volt az Unió részéről. Egyrészt egyszerre túljutott a nagy terhet jelentő keleti csatlakozáson, másrészt a tagállamok érdekei is maradéktalanul érvényesültek, hiszen mindenki „kedvence" bekerült, s nem utolsó sorban nem okozott újabb törésvonalakat a térségben (Ágh 2006b).

Horvátország, mint a Nyugat-Balkánhoz tartozó állam, s a térség számára kialakított Stabilizációs és Társulási Folyamat részese számára hosszú ideig úgy tűnt, hogy az Unió együttesen kezeli a térség államait. Amikor azonban a Bizottság 2006. november 8-án elfogadott Bóvitési stratégia és föbb kihivások 2006-2007 címú dokumentuma megjelent, ez új perspektívát rajzolt fel az ország számára. Ebben körvonalazódott az a stratégia, mely elveti a csoportos bỏvitést, de nem foglalt állást abban a kérdésben, hogy vajon hány hullámban fog mindez megvalósulni. 1981 óta először villant fel annak a reális esélye, hogy egy ország - Horvátország - egyedül csatlakozhasson, anélkül, hogy be kellene várnia társait. Ez azt a kételyt veti fel, hogy a nemzeti ratifikációk elhúzódása miatt a további bỏvítési folyamat nagyon fragmentálttá válhat, ami további kérdéseket - pl. mégis csak csoportosan kellene bővíteni - generál, annál is inkább, mert a Közösség az eddigi tapasztalatok alapján jobban kedveli a kiscsoportos bővítéseket.

A koppenhágai kritériumok megfogalmazásakor még nem volt világos, hogy az csak a keleti bővítésnél kerüljön-e alkalmazásra, vagy hatályát a későbbiekre is kiterjesszék. Mára már egyértelmú, hogy minden további, így a horvát csatlakozás esetében is meghatározó marad (Avery-Cameron 2001).

A koppenhágai kritériumok nem jelentik a csatlakozáshoz szükséges kívánalmak lezárását, ugyanis azóta is új feltételek jelentek meg, illetve a régiekben kisebb módosítások realizálódtak. Történt ez annak ellenére, hogy a 2001. évi decemberi Laekeni csúcstalálkozón kimondták, hogy a csatlakozó országokkal szemben nem lehet állandóan növelni a követelményeket. Ráadásul az EU az egyes országok számára speciális és egyedi kívánalmakkal is elóáll ${ }^{7}$. A változásokat és a további bővítések elötti nehezítéseket nagyon pontosan tükrözi a tárgyalási fejezetek számának megemelése. Amíg a keleti bővítés esetén az acquist 31 tárgyalási fejezetre 
osztották, ma a tárgyalási pozícióban lévő Horvátországnak és Törökországnak 35 fejezeten kell sikeresen tủlesnie a csatlakozáshoz (Grabbe 2003a).

A kondicionalitás terén új elemek is jelentkeznek a Nyugat-Balkán integrálása kapcsán. Az új kritériumok túlnyomó része a Stabilizációs és Társulási Folyamatból adódik, $s$ olyan feltételeket szab, mint a menekültek visszatérése, együttmüködés a hágai Nemzetközi Törvényszékkel, a kisebbségek jogainak garantálása. Nagyon valószínủ, hogy ezek bármely korábbi bővitésnél is szerepeltek volna, ha a tagjelölt hasonló gondokkal küszködött volna, mint a Nyugat-Balkán államai (Pippan 2004; Samardžija 2007).

Az új kritériumok közül a kisebbségek helyzetének és jogainak napirenden tartása további kérdéseket vet fel. Vajon milyen jogon kéri számon az Unió a kisebbségvédelmet a nyugat-balkáni államoktól, ha önmagának sincsen erre kidolgozott rendszere, ha ez nem része az acquisnak, söt mi több, maga a nemzeti kisebbség fogalom sem szerepel a Közösség egyetlen hivatalos dokumentumában sem. Ez a hiányosság megmagyarázza azt is, hogy a keleti bővítés előtt - ahol szintén hangsúlyos kritérium volt a kisebbségek védelme - az Unió láthatóan pozití hatással volt a kisebbségek helyzetére, de amint ezen államok EU-tagok lettek és a Közösség ellenörző szerepe megszünt, ez a nemzetiségek helyzetének csatlakozás utáni roszszabbodását idézte elő (mint ahogy azt tapasztalhattuk Szlovákiában és Romániában) (Tabajdi 2007).

Már a rendszerváltó országok belépésekor megfogalmazódott, de a Nyugat-Balkán esetében hangsúlyozottabban szerepel a jószomszédi viszony kialakítása. Az 1999. évi Helsinki Európai Tanács is írásba foglalta, hogy a tagjelölteknek ,minden eröfeszitést meg kell tenniük a fennálló határviták rendezésére" (European Council 1999).

Új elem viszont a regionális együttmúködések erősitésének állandó hangoztatása. Ebben a kérdésben érthető az Unió álláspontja, hiszen nem kívánja a térség országai közötti vitákat beengedni az EU-ba, csak ezen nézeteltérések rendezése után, egy viszonylag „békés” régiót hajlandó integrálni. Az is látható, hogy a Közösség nem következetes, és csak 2004 után, vagyis jelenleg a Nyugat-Balkán esetében ragaszkodik a feltétel maradéktalan teljesítéséhez. Ezt példázza Horvátország és Szlovénia máig meglévő ellentéte, mely nem újkeletü és az önállóvá válás óta terheli a két ország kapcsolatát. Szlovénia számára mégsem vált a kérdés rendezése csatlakozási kritériummá. Így állt elő az a helyzet, hogy Szlovénia csatlakozása után, EU-tagállamként „eröpozícióból" kívánja megoldani a problémát, nem egyszer megfenyegetve Horvátországot a tárgyalások lassításával, esetleges akadályozásával, mely 2008 decemberében több tárgyalási fejezet megnyitását is megakadályozó vétóba torkollott.

Szintén új elem annak a korábban magától értetődő feltételnek a gyakori és nyílt emlegetése, hogy a leendő tagállamoknak végre kell hajtaniuk az EU-val kötött megállapodásokban foglaltakat, vagyis a Nyugat-Balkán államainak a Stabilizációs és Társulási Megállapodást. Amíg a 2004-es bővitésnél a hangsúly az acquis elfogadására helyeződött, addig jelenleg annak teljesítésére. Ezt emeli ki a Horvátországról készített avis, akárcsak a Törökország és Horvátország számára összeállított tárgyalási keretprogram, mely szerint a csatlakozás feltétele „az acquis átvétele 
és végrehajtása a megfelelö adminisztrativ és igazságszolgáltatási rendszeren keresztül' (European Council 2002; 2005).

Nem arról van tehát szó, hogy ezek a feltételek korábban nem álltak volna fenn, csupán arról, hogy explicitté váltak. Megváltozott a feltételek elfogadásának dinamikája, a szabályok sokkal szigorúbb betartására kötelezik a jelölteket. Amíg korábban a csatlakozás utánra is elhúzódhatott a teljesítés, most mielött a tárgyalási fejezetek végleg lezáródnának a végrehajtásnak is be kell fejezödnie (Phinnemore 2006).

A 2004-es bỏvítés tapasztalataira építve a csatlakozási folyamat új eleme a „benchmarking”, mely szerint a csatlakozás előtt álló országoknak egyes fejezetek megnyitása, illetve ideiglenes lezárása elött, sőt elviekben az is előfordulhat, hogy mindkettő esetében elözetes feltételeket (benchmark) kell teljesítenie, nagymértékben lassítva ezzel a csatlakozási folyamatot. Ezzel ellentétben a keleti bővítéskor a fejezetek tárgyalása közben kérték be a hiányzó adatokat, így az nem volt negatív hatással az időbeliségre.

A követelmények szigorodása lehetỏvé teszi az EU számára, hogy bármikor elégedetlenségét fejezze ki a tagjelölt előmenetelével kapcsolatban, $\mathrm{s}$ ezen biztonsági fékek lelassíthatják a csatlakozást. Ilyen volt Románia és Bulgária esetében a védzáradék, mely precedens értékủ lehet a további bỏvítéseknél, de szintén jelzésértékủ a Parlament szavazása, melynek során Románia az eddigi legalacsonyabb támogatást (68\%) kapta.

2004-ig a gyakorlat az volt, hogy a tárgyalások sikeres befejezése és a Csatlakozási Szerződés ratifikációja után létrejött a csatlakozás. Ma azon kívül, hogy az Uniónak jogában áll a taggá válás utáni években monitoring alá venni az újonnan érkezők teljesítményét, olyan védzáradék készülhet, mely elhalaszthatja a csatlakozás időpontját. Először Románia és Bulgária belépése kapcsán fogalmazódott meg a lehetséges új eszközök bevezetése, bár tényleges alkalmazásukra nem került sor. Az egyik, az általános védzáradék egyhangúság esetén lehetőséget adott a tagállamoknak, hogy egy évvel elhalasszák akár Románia, akár Bulgária belépését. A másik, a megerősített védzáradék pedig minősített többség esetén egy évvel visszatarthatta volna Romániát, ha súlyos hiányosságokat tapasztalnak a versenypolitika, a Schengeni Akcióterv, a külsö határok, az igazságszolgáltatás és rendỏrségi reformok, a korrupcióellenes intézkedések, a szervezett bünözési stratégia és az állami segélyezés terén történő elörelépésben (Protocol... 2005).

Nem lehet kétséges, hogy ezen két újabb intézkedés az elkövetkezendő bỏvítések kapcsán is az Unió fegyvertárának részét fogja képezni, hiszen nyilvánvaló, hogy a Közösség nyitott olyan új eszközök - akár újabbak - elfogadására is, mellyel elhalaszthatja a csatlakozást. A védzáradékok megfogalmazása a differenciálás elvének előtérbe kerülését is jelenti, hiszen ezzel fennállt az a lehetőség, hogy a két tagjelölt nem egyszerre lép be az Unióba. Ugyancsak a differenciálást erősíti, hogy bár a Közösségnek egységes politikája van a Nyugat-Balkánra, mégsem egyszerre kezdi el a tárgyalásokat a térség országaival, sokkal nagyobb teret engedve az elért eredmények és sikerek alapján az egyéni teljesítményeknek. 
A koppenhágai kritériumokhoz más, kiegészítö dokumentumok is csatlakoztak, melyek mind a bővítés jogi elemeinek számát bővítik. Így 1995-ben az Európai Tanács Madridban ismét megerősítette a Koppenhágában megfogalmazott elveket. Az 1997 decemberében az Európai Tanács luxemburgi ülése további kiegészítést tett, amennyiben bármiféle tárgyalás megkezdését a koppenhágai politikai kritériumok teljesítéséhez kötötte, míg a gazdasági feltételek, valamint az uniós tagságból eredő kötelezettségek a tárgyalások ideje alatti megvalósulását írta elő (Council... 1997).

\section{A bövités szereplöi}

Az integráció kiterjesztésének harmadik meghatározó eleme maga a bỏvítés folyamata, melyre két aspektusból kívánunk rámutatni. Egyrészt a bővítésben résztvevök és szerepük alapján, másrészt a zömében szokásjogon alapuló, az ötödik csatlakozásra kialakult bővítési menetrend bemutatásával. A TEU 49 elméletileg meghatározza a bővítés szereplöit, melyek a tagjelöltek, az EU-tagok, valamint a Közösség három fö szerve, a Tanács, a Bizottság és a Parlament, nem tesz azonban említést az Európai Tanácsról, melynek lényeges szerepe van a folyamatban ${ }^{8}$. Már a Római Szerződés, majd a TEU is jelentős jogosítványokat biztosít a tagállamoknak, de valójában az első sikertelen bővítési kísérlet óta a tagállamok nem töltik be ezt a funkciót a bỏvítésben, mert nevükben a Bizottság tárgyal, miközben a csatlakozási folyamat egésze, kezdve az egyes fejezetek megnyitásától annak bezárásáig egyhangú tanácsi határozat alapján zajlik. A tárgyalásokat miniszteriális szinten folytatják, $\mathrm{s}$ teljes egészében az uniós keretprogram alapján (Avery-Cameron 2001; Maršić 2006).

\section{A bövités menetrendje}

A bővítésben szerepet játszó fontos, de folyamatosan változó elem a kronológia. Mára már többé-kevésbé kialakult a bővítés menetrendje, melynek egy részéröl rendelkezik a TEU 49. cikke, számos elem azonban a gyakorlat és a szokásjog alkalmazásával jött létre, illetve finomodott, bỏvült (Avery-Cameron 2001; Hoffmeister 2002; Grabbe 2003a).

A fentiekben vázolt, kodifikált és soft law elemek körvonalazzák a bövítés napjainkra kialakult módszertanát, melyet Christopher Preston hat pontba szedett össze, s a szakirodalom a klasszikus bỏvítés metódusaként tart számon: ${ }^{9}$

- A tagjelölt számára kötelező az acquis teljes elfogadása és beültetése a hazai joggyakorlatba, s kizárt az állandó mentesség lehetősége.

- A csatlakozási tárgyalás nem más, mint az acquis gyakorlati megvalósítása.

- A bövülö Közösség diverzitásának növekedése miatt újabb problémák keletkeznek, melyeknek megoldására új csatlakozási eszközök kerülnek bevezetésre. 
- A csatlakozás során az új tagok csak részben készülnek fel és válnak alkalmassá a Közösség intézményrendszerébe történő integrálódásra, a hatékony müködés kereteinek megvalósitására csak a csatlakozás utáni időszakban kerül sor.

- A Közösség előnyben részesíti a hasonló helyzetben és egymással közeli kapcsolatban lévő országokkal történő csoportos tárgyalást és bövítést.

- A tagállamok a bővítés során saját egyéni érdekeiket tartják szem elött, ugyanakkor az Unió a belső problémákat exportálva keresi ezekre a megoldást (Preston 1997).

\section{A bövitések eszközei}

Preston is rámutatott arra, hogy a bövítés folyamatának növekvő komplexitása miatt újabb technikák jelennek meg, mely megállapítás különösen igaz az 1995 utáni második bővítési szakaszra. A csatlakozást megelőzóen az Európai Unió különbözö eszközök bevezetésével füzte szorosabbra kapcsolatait a volt szocialista országokkal, segitette felzárkózásukat és a feltételek teljesítését.

Az elsőt ezek közül az új típusú Társulási Szerzödések - az Európa Megállapodások (Europe Agreements) - jelentették, melyeket 1991 és 1996 között kötött meg az Unió a 10 közép-kelet-európai állammal. Ezek eredetileg a négy alapszabadság kiterjesztésére hivatottak, de valójában a szabad kereskedelem megvalósítását segítették elö, mely elsősorban a térséggel kereskedő uniós tagállamoknak kedvezett, bár a rendszerváltó országokban is hozzájárult a piacgazdaságra való átállás és a gazdasági szerkezetátalakítás megkönnyítéséhez. Az Európa Megállapodások új típusú társulási formáknak tekinthetők, mert olyan új elemeket tartalmaztak, mint a folyamatos politikai párbeszéd, a jogharmonizáció, valamint evolúciós klauzulája biztosította a társulás továbbfejleszthetöségét (Horváth 2005). Az elöcsatlakozás Essen után konkrétabb formát öltött a Fehér Könyv elfogadásával, mely dokumentum kézzelfoghatóbb útmutatást adott a jelölteknek (European Commission 1995).

Az igazi áttörést azonban 1997. július 16-án a Bizottság Agenda 2000 címü dokumentuma jelentette (European Commission 1997), melynek legfontosabb eleme, hogy együtt tárgyalta az EU jövőbeni stratégiáját és reformjait a bővités kérdésével. Ennek alapján a tagjelölt államok csatlakozásának megkönnyítésére és segítésére létrehozták az Elöcsatlakozási Stratégiát. Ennek legföbb eszköze az Unió és az érintett országok között megkötött Csatlakozási Partnerség volt. Ezen dokumentumok keretprogramot adva tartalmazták a tagállam által teljesítendö rövid és középtávú prioritásokat és az ezek végrehajtására kapható uniós támogatásokat. A teljesítés mikéntjéröl a Bizottság éves jelentései számolnak be. Az Elöcsatlakozási Stratégia részeként minden tagjelölt elkészíti saját „Közösségi Vívmányok Átvételének Nemzeti Program"-ját (National Programme for the Adoption of the Acquis; NPAA). Az Elöcsatlakozási Stratégia fontos eleme még, hogy az Unió az Előcsatlakozási Alapok (PHARE, ISPA, SAPARD, IPA) megteremtésével segítséget nyújt 
a tagjelöltnek a koppenhágai kritériumok teljesítéséhez, valamint lehetővé teszi számukra az uniós programokban való részvételt (Avery-Cameron 2001).

A koppenhágai kritériumok és a hozzá kapcsolódó dokumentumok, az Előcsatlakozási Stratégia, valamint a Bizottság éves jelentései rávilágitanak a követelményrendszer növekedésére. Ugyan a Közösség korábban is megfogalmazott bizonyos politikai kritériumokat a tagjelöltekkel szemben - Spanyolország, Görögország és Portugália esetében a demokratikus intézményrendszer és pluralizmus -, de ezek korábban soha nem érintették a csatlakozás szubsztantív elemeit. ${ }^{10}$ Mindez igazolja, hogy a bővítés az Unió belső politikájában is jelentős változásokat eredményezett. Az sem fordult még elő soha, hogy az EU ilyen szigorral és ilyen precízen betartatta volna feltételeit (Pridham 2002).

\section{A bövitések időhorizontja}

A bipoláris rend megszünése utáni megváltozott helyzethez igazodva az EK/Európai Unió meghatározta elvárásait a csatlakozás elött álló kelet-európai országok számára. A Szerződések - mint már láthattuk - soha nem rögzítették pontosan a bővítés állomásait. Ez a magyarázata annak, hogy a csatlakozás hosszú és bonyolult folyamat, s ha összevetjük a korábbi bỏvítésekkel nagy különbségeket tapasztalunk.

Ha a folyamat időhorizontját vizsgáljuk, akkor jól láthatóan leghosszabb ideig az utolsó bővítés tartott. Az első csatlakozásra a tagjelölteknek tizenegy évet kellett várniuk (ha azt az 1961-es első kérelemtől számítjuk), de a tényleges idő is majdnem hat évet vett igénybe. A keleti bỏvítésig - ahol hazánknak pl. tíz évet kellett várnia - a leghosszabb ideig Portugália és Spanyolország csatlakozása tartott, mely esetben a kérelem benyújtása és a csatlakozási szerződés aláirása között több mint nyolc év telt el. Láthatóan tehát a teljes jogú taggá válás egyre hosszabb ideig tartó folyamat, mely alól csak az EFTA országok jelentenek kivételt, ahol Finnország csatlakozásához mindössze két évre és kilenc hónapra volt szükség. A legutolsó, keleti bővítés tartott a leghosszabb ideig, melynek legfőbb okait a rendszerváltó országok eltérő gazdasági és politikai viszonyaiban kereshetjük. Az sem mellékes, hogy a belső problémákkal küszködő Unió maga sem tudott mit kezdeni a bipoláris világrend megszünése után a Közösség kapuján kopogtató tíz országgal.

Ha nem a csatlakozás hossza felől közelítjük meg a kérdést, akkor viszont azt látjuk, hogy maga a bővítési folyamat felgyorsult, hiszen amíg az Európai Közösségnek 28 évre volt szüksége ahhoz, hogy hatról tizenkét tagúvá váljon (1958-1986), addig a bipoláris rend felbomlásától számított tizennyolc év alatt (1989-2007) 15 új állammal bövült az Unió.

Érdekessé teszi a közép- és kelet-európai régió csatlakozását az a tény, hogy egészen a rendszerváltó országok belépéséig a bővítés menetrendje azonos volt, $\mathrm{s}$ mindig a harmadik állam csatlakozási kérelmének benyújtásával vette kezdetét. 2004 elött soha nem fordult elö, hogy a Közösség valamilyen módon ösztönzött volna egyes 
országokat a csatlakozási kérelem benyújtására, ez minden esetben a harmadik fél önálló döntésén alapult. Nem így a keleti bővítésnél, ahol 1993-ban Koppenhágában kilátásba helyezték a teljes jogú tagságot Közép- és Kelet-Európa társult országai számára annak ellenére, hogy közülük egyetlen egy sem jelentette be hivatalosan csatlakozási szándékát. Ez egyedülálló helyzetet teremtett, s a „felhívás” hatására az elkövetkezendő két évben mind a tíz ország benyújtotta csatlakozási kérelmét a Közösséghez ${ }^{11}$.

Megvizsgálva a 2004 előtti bővítéseket, megállapítható, hogy a jelentkezés és a csatlakozás időpontjai között direkt kölcsönhatás van, s a jelentkezés időzítése nagyon fontos. Ha túlságosan korán történik, akkor túl hosszúra nyúlik a várakozási folyamat, mely politikailag negatív hatással lehet a tagjelöltre, ezért a harmadik ország számára fontos, hogy a megfelelő időben nyújtsa be csatlakozási kérelmét.

Az időhorizont következő, nehezen kiszámítható tényezője a Bizottság véleményének elkészítése. Általában elmondható, ha ez hosszúra nyúlik, az a tárgyalások megindítására is negativ, halasztó hatállyal bír. Az is érdekes, és a szokásjog szerepére utal, hogy a Római Szerzódés szerint a Bizottság véleménye nem előfeltétele a tárgyalások megkezdésének, mégis ez minden eddigi bỏvítésnél megelőzte azt. A Bizottság - melynek a csatlakozási folyamat egészében fontos szerepe van - még egy alkalommal tudja idöben erőteljesen befolyásolni a bővítést, illetve annak hoszszúságát, nevezetesen, amikor a tárgyalások befejezésekor megfogalmazza véleményét az adott ország integrációs esélyeivel kapcsolatban.

A csatlakozás hosszára erőteljes hatással van a tárgyalások megkezdésének időpontja. Ennek meghatározása elörevetíti a Közösség azon akaratát, hogy mennyire áll ki a csatlakozásra várók mellett, $\mathrm{s}$ a keleti bővülésnél ez a késői időpont is jól tükrözi a Közösség aggályait.

Ha mindezt kivetítjük a Nyugat-Balkánra, akkor két állam - Horvátország és Macedónia - példáján kiválóan érzékelhetỏ a csatlakozás megkezdésének halasztó hatálya. Horvátország ebből a szempontból, összevetve a kelet-európai országokkal pozitív példa, hiszen 2003. február 21 -én adta be kérelmét, $\mathrm{s}$ a tárgyalások megkezdésére 2005. október 3-án került sor. Ezzel ellentétben az SAA terén élenjáró Macedónia hiába nyújtotta be a térség államai közül elsőként - 2004. március 22-én csatlakozási kérelmét, a tárgyalások megindítására mind a mai napig nem került sor.

A tárgyalások befejezésének gyorsaságát több tényezö is befolyásolja. Függ természetesen az Uniótól, a tagjelölt fejlettségétöl, akaratától, elörehaladásától, vagyis attól, mennyire gyorsan teljesíti a feltételeket. Végül az utolsó szakasz is - mely a tárgyalások befejezésétől a csatlakozásig tart -, egyre hosszabb időszakot ölel fel. Ez nem meglepő, hiszen a növekvő létszámú Unió minden tagállamának ratifikálnia kell a csatlakozási szerződést, $\mathrm{s}$ ráadásul a Parlament hozzájárulására is szükség van (Avery-Cameron 2001).

Választóvonalat lehet húzni a keleti bővités elötti és utáni korszak között azt illetően is, hogy az állam mikor vált a Közösség teljes jogú tagjává. 1995-ig ez mindig január elseje volt, mely praktikus abból a szempontból, hogy ekkor kezdődött az EU költségvetési éve, az újabb soros elnökség. A 2004-es csatlakozás ettől eltérően május elsején lépett életbe. 
Lassította a térség integrálását, hogy a Bizottság több, korábban nem létező problémával találta magát szembe. Először is soha nem kellett egyszerre tíz országról véleményt alkotnia, hiszen korábban csak az első bővítés során és az EFTA államoknál kellett egy időben négy országgal foglalkoznia. Ez soha nem látott kérdéseket vetett fel, habár az Unió az egyszeri nagy bővítés mellett döntve mindvégig azt hangoztatta, hogy külön-külön és nem egy csoportként kezeli a tagjelölteket, és teljesítményüket is önállóan fogja vizsgálni, nem összehasonlítva egymással a csatlakozni vágyókat. Annál is inkább, mert korábban jóval homogénebb csoportok léptek be a Közösségbe, a keleti bövítés kapcsán azonban a régión belüli hatalmas gazdasági, társadalmi és kulturális különbségek miatt nehéz volt azonosan kezelni a térség országait.

$\mathrm{Az}$ Európai Unió ezen alapvetései különösen igaznak bizonyulnak a NyugatBalkán esetében, melynek egységes integrálását nagyon megnehezítené a régió heterogenitása. Ezért - bár több szempontból (pl. SAP) együ̈t foglalkozik a térség országaival - alapvetően az egyéni haladást hangoztatja, növelve ezzel a reformok teljesitésében élenjáró Horvátország esélyeit.

A hosszúra nyúlt integrálási folyamatot befolyásolta, hogy a délkelet- európai tagjelöltek egy része vagy a rendszerváltáskor jött létre, vagy ekkor alakult újjá, $\mathrm{s}$ a csatlakozó államok mindegyikéről elmondható, hogy a politikai függetlenség hoszszú ideig csorbát szenvedett. Történelmük során több nagyhatalom - a Habsburg Birodalom, Törökország, Oroszország - osztozkodott rajtuk, s valójában a térségben az önálló nemzetállamok csak a 19. század végén, a 20. század elején jöttek létre. A második világháború után közös jellemzőjük a szovjet hegemónia, vagyis a tényleges függetlenség hiánya.

Ezek a történelmi hasonlóságok erőteljesen meghatározták a térség sorsát, s érthetỏvé válik az is, hogy miért tekintett a Közösség egyformán a régió államaira, melyek közül néhány de jure is csak a rendszerváltással nyerte vissza függetlenségét. Ezek között van a három Balti állam, Szlovénia ekkor szakadt el Jugoszláviától és vált önállóvá, $\mathrm{s}$ Csehszlovákia is ekkor szakadt ketté. Természetes, hogy ezekben az országokban az önálló nemzetállam megteremtése, az identitáskeresés ekkor került napirendre, mely összefonódott a demokrácia, a piacgazdaság kiépítésének nehézségeivel, s ezt kellett összeegyeztetni az euroatlanti irányultsággal. Mindez még hatványozottabban jelentkezik a Nyugat-Balkán országai esetében, ahol Jugoszlávia nem problémamentes felbomlása után jöttek csak létre az önálló államok. Pridham úgy fogalmaz, hogy a posztkommunista országok többszörös kényszerhelyzetben voltak, mert a történelmi, a modernizációs, a biztonság megteremtésének és a demokratizálásnak a kényszere egyszerre volt jelen (Pridham 2002).

A rendszerváltó országokban mindezek következtében hiányoztak az összehasonlítást lehetôvé tevő statisztikai adatok, $\mathrm{s}$ alapvetỏen mindegyik államra jellemzö volt a jogi háttér tisztázatlansága és gyors változásai, amelyek velejáróik az éppen a gazdasági és politikai konszolidáció útjára lépett államoknak. Fokozta a problémákat, hogy hiányzott a szakképzett és gyakorlott vezetöi réteg, és maguk a tagjelöltek is nehezen tudták helyzetüket elemezni és az Unióhoz füződő viszonyukat meghatározni (Wallace 2002; Grabbe 2004). 


\section{Összefoglalás}

Az Európai Unió bővítéseinek vizsgálata során megállapítható, hogy a Közösségnek nincs általánosan érvényesülö, kidolgozott, konstans bővítési stratégiája, s a bővítések menetrendjét befolyásoló függő változók és a folyamatosan megújuló, egyre mélyülő integráció áll a hátterében a csatlakozási folyamat változásainak.

A bővítés jogi szabályozása rendkívül komplex és állandóan változó tényezöként határozza meg az újabb tagállamok felvételét. Mindezt szemléletesen tükrözik a Szerződésekben a Közösséghez történő csatlakozásra vonatkozó paragrafusok, a bővítési kritériumok és szabályok, a csatlakozási folyamatban résztvevők körének és szerepének, valamint a bővítés menetrendjének változásai. A bővitési feltételek, így a koppenhágai kritériumok és a hozzá kapcsolódó dokumentumok, az Elöcsatlakozási Stratégia, a Bizottság éves jelentései egyaránt rávilágítanak a követelményrendszer növekedésére, melyben meghatározó szerepet játszik, hogy az Unió maga sem változatlan. Ugyan a Közösség korábban is megfogalmazott bizonyos politikai kritériumokat a tagjelöltekkel szemben, de ezek korábban soha nem érintették a csatlakozás szubsztantív elemeit. A rendszerváltó országok integrálása kapcsán nem csak a feltételek változása és intenzitásának növekedése, hanem szigorú, következetes betartatása is új elem, mely az Unió belső politikájában is jelentős átalakulást eredményez. Mind az alapelvek és kritériumok folyamatos változása, mind a bövítés folyamatjellege alátámasztja, hogy a Közösség eddigi bővítéseinek történetét két jól elkülöníthető szakaszra lehet osztani, így az elsỏ szakasz 1995-tel, az EFTA bövítéssel lezárul, $s$ utána új fejezetet nyit a rendszerváltó országok csatlakozása. Az éles elkülönülést igazolja, hogy a 2004 elötti bövítések módszerei, kritériumai és menetrendje nem - vagy csak részlegesen - alkalmazhatóak a keleti és a további, köztük a horvát integrációra.

\section{Jegyzetek}

'A bővitések elméleti megközelítése kapcsán a szakértök túlnyomó többsége a két megközelítés mellett teszi le voksát. Ennek alapján az egyik jelentős csoport a bővitéseket, mint az Európai Unió kủlpolitikájának fó megnyilvánulási formáját kezeli, míg a másik nagy csoport a belsô következményekre helyezi a hangsúlyt, a közös és közösségi politikák elmélyítési folyamatában betöltött szerepe alapján ítéli meg a bốvítéseket és azok hatását vizsgálja a belső integrációs folyamatokra. Györkös Péterrel, a Magyar Köztársaság Zágrábi Nagykővetsége rendkívüli és meghatalmazott nagykövetével folytatott beszélgetés alapján.

${ }^{3}$ Norvégia két esetben is hiába kapott zöld utat, a helyi népszavazás nemleges választ adott.

${ }^{4}$ Gondolunk itt olyan rendkivül gyorsan változó politikákra, mint a környezetvédelem, kisebbségvédelem, nemek egyenjogúsága, multikulturalizmus vagy az információs társadalommal összefüggỏ kérdések.

${ }^{5}$ Ha megvalósul a mai elörejelzés, és Horvátország 2009-re befejezi a tárgyalásokat, akkor várhatóan 2011-ben a magyar elnökség idején teljes jogú taggá válhat, mely azt jelenti számára, hogy elöször a rá is vonatkozó költségvetésbe csak 2013-ban lesz beleszólása.

${ }^{6}$ A Tanács kizárólagos hatásköre a bóvítés során jól tükrőzi az ESZAK erőteljesen szupranacionális jellegét. 
${ }^{7}$ Ilyen volt Bulgária, Litvánia és Szlovákia esetében a nukleáris erőmủ bezárása, vagy Romániában a gyerekekről történő szociális gondoskodásban való elörelépés.

${ }^{8}$ Néhány példa az Európai Tanács szerepéröl a bövítésben: döntés a bővítés megkezdéséről, illetve elhalasztásáról (Presidency Conclusions, 1993 Copenhagen European Council), a kondicionalitás szabályának megteremtése, koppenhágai kritériumok, döntés arról, hogy a Bizottság írjon véleményt a tagjelöltekröl, valamint valójában a csatlakozási folyamat minden fó részét felügyeli.

${ }^{9}$ A bővítéssel foglalkozó szakirodalom szinte mindenhol a Christopher Preston nevéhez füződő klasszikus bỏvítési metódust veszi alapul.

${ }^{10}$ Olyan területeket érintve, mint a civil szféra, politikai, szociális, gazdasági és kulturális jogok, kisebbségvédelem.

11 Magyarország 1994. március 31.; Lengyelország 1994. április 5.; Románia 1995. június 22.; Szlovákia 1995. június 27.; Lettország 1995. október 13.; Esztország 1995. november 24; Litvánia 1995. december 8.; Bulgária 1995. december 14.; Cseh Köztársaság 1996. január 17.; Szlovénia 1996. június 10.

\section{Irodalom}

Avery, G.-Cameron, F. (2001) The Enlargement of the European Union. Sheffield Academic Press, Sheffield.

Ágh A. (2006a) The Future of Europe as Seen from Hungary: The Need for an Enlarged Identity in an Enlarged Europe. - IPG. I. 91-104. o.

Ágh A. (2006b) Magyarország az Európai Unióban. Az aktiv Európa-politika kezdetei. Századvég Kiadó, Budapest.

Balázs P. (2001) Európai egyesülés és modernizáció. Osiris Kiadó, Budapest.

Council of the European Union (1997) Presidency Conclusions: Luxembourg European Council, Introduction. Brussels.

European Commission (1995) White Paper: Preparation of the Associated Countries of Central and Eastem Europe for Integration into the Intemal Market of the Union. COM (95) 163.

European Commission (1997) Agenda 2000: For a Wider and Stronger Union. Offical Journal of the European Communities. COM (97) 2000 final, 13 July, Luxembourg.

European Commission (1999) Commission Communication to the Council and European Parliament on the Stabilisation and Association Process for the Countries of South-Eastern Europe. COM (99) 235. Brussels.

European Commission (2001) Council Decision Concerning the Signature of the SAA between the European Communities and its Member States and the Republic of Croatia on behalf of the European Community. COM (2001) 371 final, 9 July. Brussels.

European Council (1993) Presidency Conclusion of the Copenhagen European Council. Office for Offical Publications of the European Communities, Luxembourg.

European Council (1999) Declaration of the Helsinki European Council. 10 and 11 December 1999 , Presidency Conclusions, Document 00300/1/99, 11 December, Brussels.

European Council (2002) Negotiating Framework for Turkey, 22. http://ec.europa.eu/ enlargement/pdf/st20002_05_TR_framedoc_en.pdf Letöltés dátuma: 2007. 11. 22.

European Council (2005) Negotiating Framework for Croatia Accession. Luxembuourg, 3 October 2005. http://ec.europa.eu/enlargement/pdf/croatia/st20004_05_HR_framedoc_en.pdf Letöltés dátuma: 2007. 11. 22.

Egységes Európai Okmány. (1986) The basic treaties of the European integration (ECSC, EURATOM, EEC, SEA, TEU, TA, TN) http://europa.eu.int/eur-lex/lex/en/treaties/index.htm Letöltés dátuma: 2007. 10. 21 .

Fazekas J. (szerk.) (2001) Az európai integráció alapszerződései. KJK-KERSZÖV, Budapest.

Friis, L.-Murphy, A. (1999) The European Union and Central and Eastem Europe: Govemance and Boundaries. - Journal of European Public Policy. 2. 211-232.0.

Gazdag F.(2005) Európai integráció és külpolitika. Osiris Kiadó, Budapest.

Ginsberg, R. (1989) Foreign Policy Actions of the European Community: The Politics of Scale. Lynne Rienner, Boulder.

Glenn, J.K. (2003) The EU Enlargement. - Cini, M. (ed.) European Union Politics. Oxford University Press, Oxford. 211-228. o. 
Grabbe, H. (1999) A Partnership for Accession? The Implications of EU Conditionality for the Central and East European Applicants. - Robert Schuman Centre Working Paper. No. 12/99. European University Institute, Florence.

Grabbe, H. (2000) The Sharp Edges of Europe: Extending Schengen Eastwards. - International Affairs. 3. 519-536. o.

Grabbe, H. (2001) Profiting from EU Enlargement. Centre for European Reform, London.

Grabbe, H. (2003a) The Implications of EU Enlargement. - White, S.-Lewis, P.-Batt, J. (eds.) Developments in Central and Eastern European Politics 3, Palgrave. 253-266. o.

Grabbe, H. (2003b) The Process of EU Accession: What Will it Bring to Southeast Europe? Global Development Network Southeast Europe, London.

Grabbe, H. (2004) The Constellations of Europe. How enlargement will transform the EU. Centre for European Reform, London.

Hill, C. (2000) The Geo-political Implications of Enlargement. - EUI working paper, RSC. No. 2000/30.

Hillion, C. (2002) Enlargement of the European Union: A Legal Analysis. - Amull, A.-Wincott, D. (eds.) Accountability and Legitimacy in the European Union. OUP, Oxford. 401-418.o.

Hoffmeister, F. (2002) Changing Requirements for Membership. - Ott, A.-Inglis, K. eds.) Handbook on European Enlargement. T. M. C. Asser Press, Hague.

Horváth Z. (2005) Kézikönyv az Európai Unióról. HVGORAC, Budapest.

Inotai A. (1997a) Miért újszerú az Európai Unió keleti kibővülése? - Európai Tükör. 3. 1-11. o.

Inotai A. (1997b) Útközben. Magyarország és az Európai Unió. Tanulmányok. Belvárosi Könyvkiadó, Budapest.

Maršić, T. (2006) Assessing the negotiation experience: quick accession or good representation. - Ott, K. (ed.) Croatian accession to the European Union: the challenges of participation. Institute of Public Finance-Friedrich Ebert Stiftung, Zagreb. 29-56. o.

Monar, J. (2000) Enlargement-Related Diversity in EU Justice and Home Affairs: Challenges, Dimensions and Management Instruments. Scientific Council for Government Policy, Hague.

Moravcsik, A.-Vachudova, M.A. (2003) National Interests, State Power, EU Enlargement. - East European Politics and Societies 1. 42-57.0.

Phinnemore, D. (2003) Stabilisation and Association Agreements: Europe Agreements for the Western Balkans. EFA Rev. 77. 7-26, o.

Phinnemore, D. (2006) Beyond 25 - the Changing Face of EU Enlargement: Commitment, Conditionality and the Constitutional Treaty. - Journal of Southern Europe and the Balkans. 1. 7-26. o.

Pierson, P.(1995) The Path to European Integration: A Historical Institutionalist Perspective. Centre for European Studies working paper. No. 58. Harvard, Boston.

Pippan, C. (2004) The rocky road to Europe: the EU's Stabilisation and Association Process for the Western Balkans and the principle of conditionality. - European Foreign Affairs Review. 2. 219-245, o.

Preston, C. (1997) Enlargement and Integration in the European Union. Routledge, London.

Pridham, G. (2002) EU Accession and Domestic Politics: Policy Consensus and Interactive Dynamics in Central and Eastern Europe. - Cameron, R. (ed.) Perspectives on the Enlargement of the European Union. Brill, Leiden - Boston - KöIn. 49-74. o.

Protocol Concerning the Conditions and Arrangements for Admission of Bulgaria and Romania to the European Union. (2005) Brussels, 31 March 2005. Official Journal of the European Union. L 157/29.

Samardžija, V. (2007) Enlargement on Crossroad: Prospects for Croatia and South-Eastern Europe. Ágh, A.-Ferencz, A. (eds.) Overcoming the EU Crisis: EU Perspectives after the Eastern Enlargement. The Together for Europe Research Centre and Foundation, Budapest. 107-131. o.

Santer, J. (1997) European Commission Press Release. IP/97/660, DOC 97/9, 16 July 1997., Brussels. http://www.zei.de/download/zei_dp/dp_c59_sanader.pdf Letöltés dátuma: 2005. 10. 25.

Schimmelfennig, F. (2005) Liberal community and Enlargement. An event History Analysis.Schimmelfennig, F.-Sedelmeier, U. (eds.) The Politics of European Union Enlargement. Theoretical Approaches. Routledge, London.

Schimmelfennig, F.-Sedelmeier, U. (2005) The Politics of EU Enlargement. Theoretical and Comparative Perspectives. - Schimmelfennig, F.-Sedelmeier, U. (eds.) The Politics of European Union Enlargement. Theoretical Approaches. Routledge, London.

Schmitter, P. (1996) Imagining the Future of the Euro-Polity with the Help of New Concepts. - Gary, M.Fntz, S.-Philippe, C.S.-Wolfgang, S. (eds.) Governance in the European Union. Sage, London. 121-150. o.

Sedelmeier, U. (2003) EU Enlargement, Identity and the Analysis of European Foreign Policy: Identity Formation Through Policy Practice. - EUI Working Papers. RSC No. 2003/13. Robert Schuman Centre for Advanced Studies. European University Institute, Florence. 
Tabajdi Cs. (2007) The Western Balkans and the European Union Today. - Glatz, F. (ed.) The European Union, the Balkan Region and Hungary. Europa Institut, Budapest. 65-77. o.

Wallace, W. (2002) Enlarging the European Union - An Overview. - Cameron, R. (szerk.) Perspectives on the Enlargement of the European Union. Brill, Leiden - Boston - Köln. 1-18. o.

Zielonka, J. (2001) How New Enlarged Borders will Reshape the European Union. - Journal of Common Market Studies. 3. 507-536. o. 